\title{
Labor Productivity Convergence in Indonesia: Spatially Dynamic Panel Data Analysis
}

\author{
By: \\ Ahmad Fajar Novianto ${ }^{1 *}$, Waris Marsisno ${ }^{2)}$ \\ ${ }^{1)}$ Statistics Indonesia (BPS) \\ ${ }^{2)}$ Statistics, Politeknik Statistika STIS \\ ${ }^{*}$ Corresponding Author: ahmadfajarnovianto@gmail.com
}

\begin{abstract}
The problem of labor productivity in Indonesia is a regional and sectoral inequality. The time required to remove inequality can be measured by the level of convergence of labor productivity. This research aims to analyze the rate of sectoral labor productivity convergence among provinces in Indonesia spatially and to identify the determinant factors of labor productivity. The analytical methods used is spatial dynamic panel data with Spatially Corrected Blundell-Bond (SCBB) estimation method. The results show that there is spatially sectoral labor productivity convergence. Primary sector takes the longest half-life convergence of 7-8 years, while secondary takes 1-2 years and tertiary sector takes 3-4 years. Furthermore, the Gross Capital Fixed Formation, mean years of schooling, and sectoral real wage significantly have positive effect on the labor productivity while life expectancy significantly has negative effect on labor productivity.
\end{abstract}

Keywords : Convergence, Spatial Analysis, Labor Productivity

\begin{abstract}
ABSTRAK
Permasalahan produktivitas tenaga kerja di Indonesia adalah ketimpangan regional dan sektoral. Waktu yang dibutuhkan untuk menutup celah ketimpangan tersebut, dapat diukur dengan tingkat konvergensi produktivitas tenaga kerja. Penelitian ini bertujuan menganalisis tingkat konvergensi produktivitas tenaga kerja sektoral antar provinsi di Indonesia secara spasial dan mengidentifikasi faktor-faktor yang mempengaruhi produktivitas tenaga kerja. Metode analisis yang digunakan adalah analisis regresi spasial data panel dinamis dengan metode estimasi Spatially Corrected Blundell-Bond (SCBB). Hasil penelitian menunjukkan bahwa terdapat konvergensi spasial produktivitas tenaga kerja sektoral. Sektor primer membutuhkan waktu half-life convergence terlama yaitu 7-8 tahun, sedangkan sektor sekunder 1-2 tahun dan sektor tersier 3-4 tahun. Selanjutnya, Pembentukan Tetap Modal Bruto, Rata-rata Lama Sekolah, dan sektor upah riil secara signifikan berpengaruh positif terhadap produktivitas tenaga kerja sedangkan Angka Harapan Hidup secara signifikan berpengaruh negatif terhadap produktivitas tenaga kerja.
\end{abstract}

Kata Kunci: Konvergensi, Analisis Spasial, Produktivitas Tenaga Kerja 


\section{INTRODUCTION}

The welfare and prosperity of the country are largely determined by the economic development. Idris (2016: 18) explained that the economic development also includes other aspect such as the quality of society. Therefore, in order to improve the economic development, besides focusing on income growth, other aspects for examples inequality, unemployment, and other socio-economic aspects should be considered. The study of the economy can also be seen from a labor perspective. According to Bhinadi (1997: 40), output per labor (or often called by labor productivity) is an important indicator of economic welfare that can be used to study and analyze the regional disparity and economic growth. Labor productivity can be defined as the level of productivity that can be produced by a labor in a certain time (Sukirno, 2012, p. 352).

Labor productivity in Indonesia showed an increasing pattern every year as shown in Figure 1. However, the labor productivity growth could not grow stably as targeted by the government. The Directorate General of Training and Productivity Development (Ditjen Pembinaan Pelatihan dan Produktivitas) through Regulation of the Minister of Labor and Transmigration of the Republic of Indonesia No. 5/2014 on Determination of Performance Indicators of the Ministry of Labor and Transmigration 2014-2019 has set an increasing labor productivity percentage per year. From this target, the achievement of the target is quite low. It can be seen that only in 2013 and 2014, the target can be realized. This fact indicates that there are still problems in the growth of labor productivity, which could not grow consistently. Therefore, the effort from the government is needed to boost and maximize the growth of labor productivity consistently so that the labor can compete and produce optimal economic output.
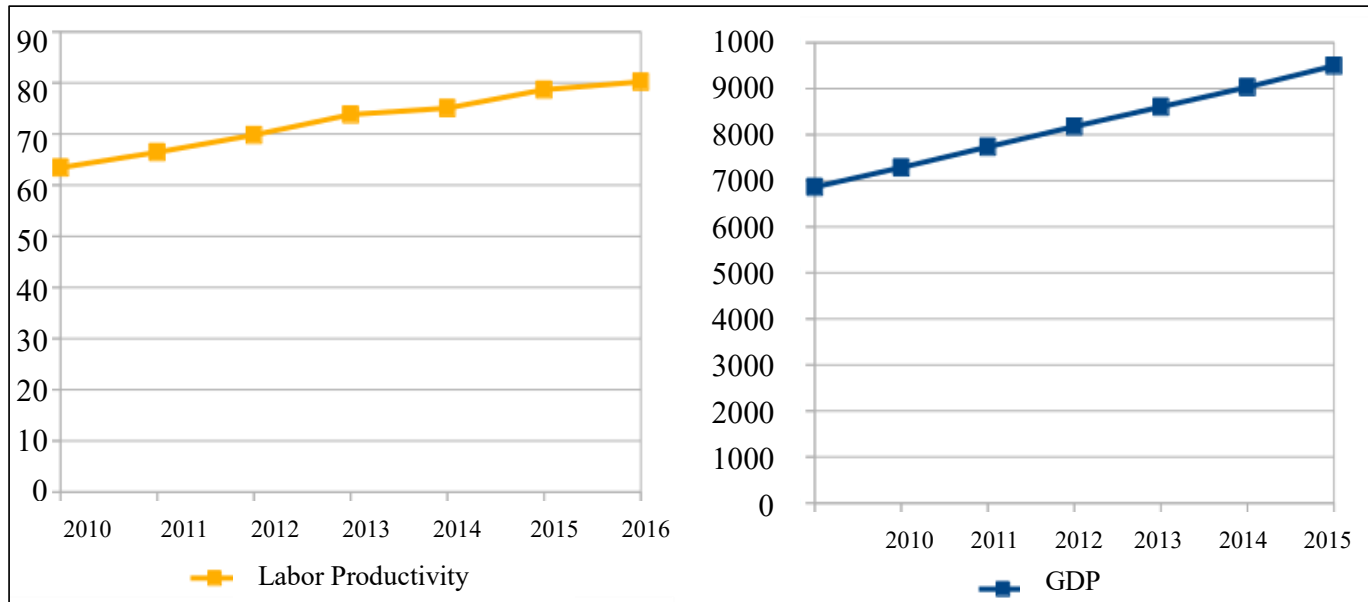

Figure 1. Labor productivity value (million rupiah / labor) and Indonesia's Gross Domestic Product (million rupiah) in 2010-2016

Source: Statistics Indonesia (BPS)

The increasing economic output should be followed by equity. As shown in Figure 2, in 20102016, the achievement of economic development in Indonesia still need to be evaluated. Because the average level of inequality as measured by Gini Index is 0.403 . Based on this figure, it can be said that Indonesia has a moderate range of inequality. Nevertheless, the inequality between provinces in Indonesia, since 2011, began to gradually decline until the end of 2016. 


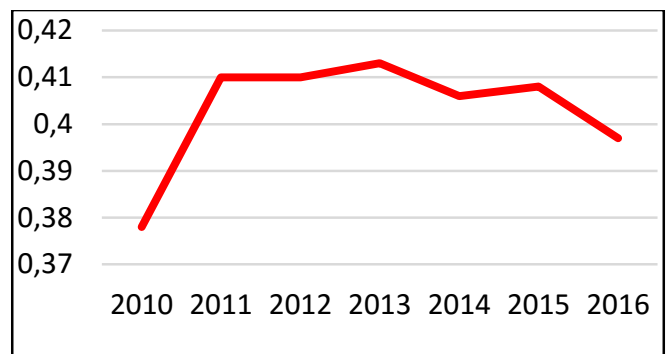

Figure 2. Indonesia's Gini Index in 2010-2016

Source: Statistics Indonesia (BPS)

Besides the regional inequality, sectoral inequality also occurs in Indonesia. Until August 2016, the majority of Indonesia's population are working in the Agriculture, Forestry, Hunting, and Fisheries sector by $31.90 \%$. On the other side, based on the value of labor productivity, the dominant sector is the Mining and Excavation sector and the Financial sector. In 2015, the labor productivity of the Mining and Excavation sector reached the highest point in 2010-2016 with 196.425 million rupiahs. It was well above other sectors.

In Indonesia, research on disparities and determinants of labor productivity has been done by Fitri, Firdaus, and Fahmi (2013) who used panel data analysis with Sys-GMM estimation techniques. The results of the study stated that the stock of physical capital, the stock of human capital, total trade, and real wages have a positive impact on the growth of labor productivity. The concept of labor productivity convergence was also adopted in Susanti's (2005) study. The study shows that there is a decrease in the disparity in the sectoral labor productivity between provinces in Indonesia. The weaknesses of the previous studies that have been done in Indonesia is that it was not considering the geographical component, so there is still a correlation between residuals.

Referring to Susanti (2005), a geographical component that has a relationship with regional economic growth can lead to integration between regions. Areas with higher growth rates are usually clustered and concentrated. The spatial effect means that a country's economic condition does not result from the economic situation in the country itself, but also because of the economic development of the neighboring countries (Calvo and Reinhart, 1996). Le Gallo and Dall'erba (2008) applied the concept of economic convergence of labor productivity convergence between countries in Europe with a sectoral and spatial approach. The study uses a spatial panel data regression analysis model, while the model specifications adopted are Spatial Error Model (SEM). The results of the study stated that there is convergence at the same steady state level at the aggregate and sectoral levels, (i.e. energy and manufacturing sector). The study also showed significant spatial autocorrelation.

This study tries to include spatial elements to explain the economic linkages, especially labor productivity among provinces in Indonesia. Thus, the effects of a region will be known for other regions which are very beneficial for the implementation of regional policies. As is well known that Indonesia adheres to the regional autonomy system. Therefore, this research is expected to be taken into consideration in order to realize economic growth that is evenly distributed throughout Indonesia related to the development of human resources.

From the backgrounds, the purpose of this research is as follows: (1) to provide the general description of sectoral labor productivity in Indonesia, (2) to analyze the level of convergence of sectoral labor productivity in Indonesia, and (3) to analyze the linkages of spatial as well as sectoral productivity of labor between provinces in Indonesia and its determinants. 


\section{METHOD}

This research uses panel data from 2010-2016 covering 33 provinces in Indonesia. The focus of this research is to measure labor productivity in 3 sectoral level, namely the primary, secondary and tertiary sectors. This research uses secondary data obtained from the publication of the StatisticsIndonesia (Badan Pusat Statistik - BPS).

In this research, descriptive analysis with graphs was used to provide a general overview of labor productivity in Indonesia. The thematic map of labor productivity is also used to add more general description. The maps are categorized into four groups, they are very high, medium-high, medium-low, and very low using natural break categorization methods.

Table 1. Operational Definition Of Variables

\begin{tabular}{|c|c|c|c|}
\hline Variable & Description & Operational Definition & Unit \\
\hline LP & $\begin{array}{l}\text { Labor } \\
\text { productivity }\end{array}$ & $\begin{array}{l}\text { Real GDP divided by the number of population aged } 15 \\
\text { years and over who worked during the past week }\end{array}$ & $\begin{array}{l}\text { Billion } \\
\text { rupiah }\end{array}$ \\
\hline GFCF & $\begin{array}{l}\text { Gross Fixed } \\
\text { Capital } \\
\text { Formation }\end{array}$ & The ratio between the GFCF and the total of GDP & - \\
\hline LE & Life Expectancy & $\begin{array}{l}\text { The average year of life that will still be lived by } \\
\text { someone until the age of } x \text {, in a mortality situation that } \\
\text { applies in the community. }\end{array}$ & Years \\
\hline MYS & $\begin{array}{l}\text { Mean Years of } \\
\text { Schooling }\end{array}$ & $\begin{array}{l}\text { Number of years of study of residents aged } 15 \text { years and } \\
\text { over who have been completed in formal education. }\end{array}$ & Years \\
\hline RW & Real wage & $\begin{array}{l}\text { Monthly wages / salaries / net income divided by } \\
\text { implicit indices }\end{array}$ & Rupiah \\
\hline W & $\begin{array}{l}\text { Spatial weight } \\
\text { matrix }\end{array}$ & Risen labor migration based on SUPAS 2015 & \\
\hline
\end{tabular}

In addition, another descriptive analysis used is the analysis of sigma convergence using coefficient of variation. The value of the sigma convergence used in this study is expressed in the following formula.

Where:

$$
C V=\frac{\sqrt{\sum_{i=1}^{n}\left(y_{i}-\vartheta\right)^{2}\left(\frac{L_{i}}{L}\right)}}{y}
$$

$y_{i} \quad:$ labor productivity in the $i$-th province

$\bar{y} \quad$ : average of the Indonesia labor productivity

$L_{i} \quad$ : number of labor in the i-th province

$L \quad$ : number of labor in Indonesia

Inferential analysis used in this research is the analysis of beta convergence. Beta convergence itself is divided into two sub analyses: absolute beta convergence and conditional beta convergence. The absolute beta convergence parameter does not consider spatial effects. Parameter estimation does on the dependent variable by the dependent lag variable itself. Meanwhile, parameter estimation on conditional beta convergence equation includes independent variables and the control variable, namely the spatial effects.

The use of dependent lag variable in the estimation can be potential to cause inappropriate results (Millo and Piras, 2012). The use of ordinary OLS estimates in dynamic panel equations will 
be biased and inconsistent (Baltagi, 2005). Therefore, this research uses a dynamic spatial panel data model that considers the spatial dependence in the dependent variable (in its error form). The analysis to estimate the parameters is the Spatially Corrected Blundell-Bond (SCBB). It is a dynamic panel spatial method which is the development of the Sys-GMM method with a two step nonconstant estimation.

The estimation results in the absolute and conditional convergence equation will give a convergence time indicator. Beta convergence (absolute and conditional convergence) will produce two indicators, namely the rate of convergence and half-life convergence. The rate of convergence measures the rate of speed of labor productivity convergence to a steady state condition (the level of equilibrium where the labor productivity rate between provinces will be similar to each other). The rate of labor productivity convergence is calculated based on the formula (Hasriati, 2016):

$$
\lambda=\frac{-\ln (\beta)}{T} ; T=\text { the number } \text { of time period }
$$

This study uses annual data, so the value of $T=1$. Thus, the value of $\lambda$ can be expressed as $\lambda$ $=-\ln (\beta)$. The half-life value shows the time needed to achieve half of the time of labor productivity convergence, which is formulated as follows:

$$
t^{*}=\frac{-\ln (0,5)}{\ln (\beta) / T}=\frac{\ln 2}{\lambda}
$$

When using dynamic spatial panel data regression method, there are several stages of analysis that need to be done as follows.

(1) Selecting a spatial weight matrix that can explain the spatial dependence of labor productivity between provinces in Indonesia.

(2) Developing conditional beta convergence model with dynamic panels with spatial effects. The results of this model will show variables that can explain the convergence of labor productivity per sector.

(3) The model will be estimated by the Spatially Corrected Blundell-Bond (SCBB) method including endogenous lag variables as instrument variables.

(4) Testing the model specifications with the Arellano-Bond test ( $A B$ test) and test the Sargan to get a model with an unbiased, consistent, and valid instrument estimator. In addition, Wald test also has to be done to find out at least one of the variables that have a significant effect on labor productivity.

(5) Interpreting the best model equations.

Furthermore, the spatial effects used in this research adopts a model from the research of Kukenova and Monteiro (2009) and Hasriati (2016) which has been modified by focusing only on spatial dependence in the autoregressive spatial model (Spatial Lag Model). Based on the research of Bouayad-Agha and Lionel (2010), LM test to determine the effect of spatial dependence is unavailable for dynamic panel data models, so that in this research, the author only focused on spatial lag methods. Thus, the model specifications used in this study are:

$$
\begin{aligned}
\ln \left(L P_{i t}\right)_{k}=\delta_{k} & \ln \left(L P_{i(t-1)}\right)_{k} \\
& +\lambda_{k} \sum_{j=1}^{n} w_{i j} \ln \left(L P_{j t}\right)_{k}+\beta_{1 k} \ln \left(G F C F_{i t}\right)_{k}+\beta_{2 k} \ln \left(L E_{i t}\right)+\beta_{3 k} \ln \left(M Y S_{i t}\right) \\
& +\beta_{4 k} \ln \left(R W_{i t}\right)_{k}+\left(\rho_{k} \sum_{j=1}^{n} w_{i j} \varepsilon_{j t}+v_{i t}\right)
\end{aligned}
$$


Where:

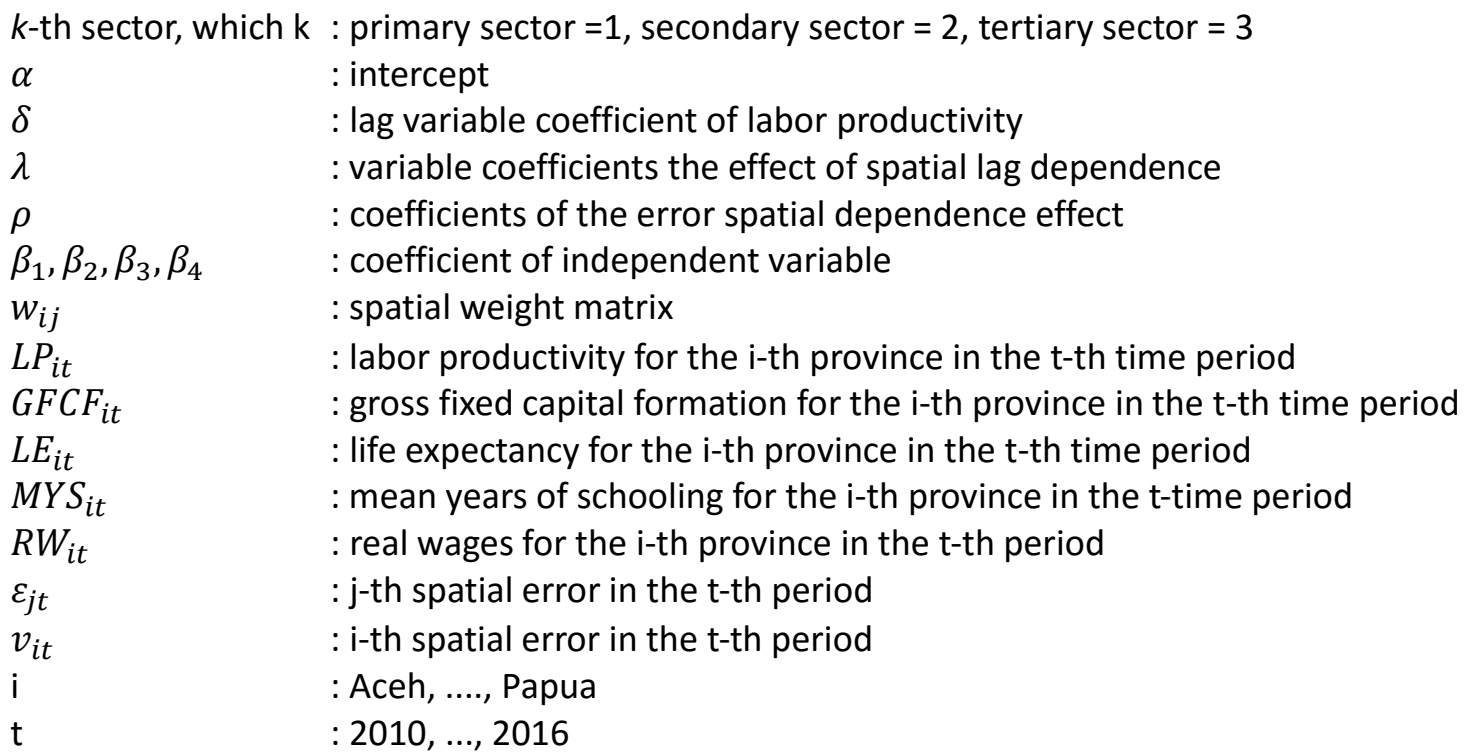

\section{RESULT AND DISCUSSION}

In aggregate level, the labor productivity in Indonesia tends to increase. In 2010, a labor, on average, can produce an output of 69.11 million rupiah per year. This figure increased to 85.36 million rupiah per year in 2016 with an average growth of $4.15 \%$ per year. However, Indonesia still has labor productivity problems because there are very few provinces that are grouped into the category of very high and high middle productivity. The figure below shows that in general the gap of labor productivity still occurs between provinces in Indonesia. Most provinces in Indonesia are still in the middle to lower and even very low category. When compared to other provinces, the provinces on Sumatra Island are generally grouped into the lower middle category. West Papua and Papua have medium labor productivity levels. The provinces in Nusa Tenggara and Maluku need to get special attention from the government because of the low level of labor productivity in the area.

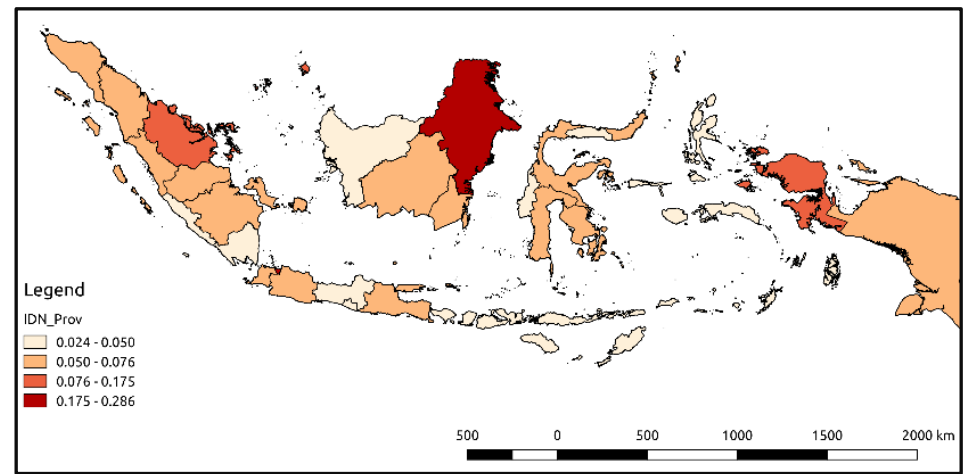

Figure 3. Thematic Maps of Average Aggregate Labor Productivity in Indonesia 2010-2016

The primary sector has the lowest labor productivity compared to other sectors. On average, each labor in the primary sector can produce output of 65.04 million rupiah per year. Whereas in the secondary and tertiary sectors, a labor can produce outputs of 128.48 and 65.77 million rupiah per year. The low level of productivity of the primary sector, when compared to other sectors, is an indication of the importance of government attention to improve in the transformation of employment. This is due to the fact that a large number of labors in Indonesia work in the agricultural sector. On the other hand, the secondary and tertiary sectors have high output demand. 
According to Permata and Prasmuko (2010) which corresponds to Lewis' growth theory, if there is a change in demand for output in a sector, it will cause a change to labor requirements that can trigger a labor shifting to other sectors. If some of the labors moved from the agricultural sector, the sector will not lose its output. In reality, it is still difficult for the agricultural sector labors to switch and move to other sectors because the secondary sector requires more qualified labors.

In the period 2010-2016, East Kalimantan Province became the province with the highest labor productivity in the primary sector with an average value of 446.60 million rupiah per labor per year because the agriculture and mining sectors dominated the economic activities in there. The average contribution of the primary sector to the total GRDP in East Kalimantan is $57.15 \%$. The great potential in coal commodities is the key to the economic progress of East Kalimantan. Based on data from the Mining and Energy Office of East Kalimantan, in 2015 the total coal production in East Kalimantan reached 236.613 million tons. In addition, palm oil is also able to sustain the economy. The palm oil production reached 9,628,072 tons in 1,020,413 ha plant area ${ }^{1}$. Meanwhile, the Province of East Nusa Tenggara (NTT) became the province with the lowest primary sector productivity level with an average of only 11.92 million per labor per year. This is because the mining sector is unable to contribute much to the economy which is only lower than $2 \%$ of the total GRDP of NTT. Whereas in the agricultural sector, which is the largest contributor to GRDP, there are still human resource problems. The human resource education in NTT is very low. There are $60.65 \%$ of NTT farmers who only graduated from elementary school (NTT in Figures 2016 publication).

Furthermore, in the secondary sector, DKI Jakarta Province is able to produce an average productivity of 470.97 million rupiah per labor per year in the period 2010-2016. The manufacturing industry sector still has a large influence on the economy of DKI Jakarta. This is indicated by the contribution of the manufacturing industry sector to GDP at 13.84 percent in 2015, which is the second largest contribution after the Wholesale \& Retail Trade, Car and Motorcycle Repair sectors. Therefore, the development and economic growth of DKI Jakarta will still be affected by the development of the manufacturing industry sector. The province with the lowest labor productivity levels is DI Yogyakarta. On average, a labor in DI Yogyakarta is only able to produce an output of 34.06 million rupiah per year in the period 2010-2016. Although the Manufacturing Industry Sector is the largest contributor to GDP, which is $13.21 \%$, in reality it has not been able to increase the secondary sector labor productivity. It is possibly caused by the economy of DI Yogyakarta, which is mainly based on the tertiary sector (66.27\%).

As for the tertiary sector, the DKI Jakarta Province in the 2010-2016 period was able to

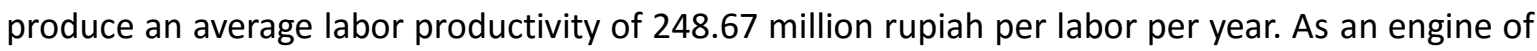
the national economy, DKI Jakarta is able to reap a large investment from investors. The amount of investment in the tertiary sector is the reason for the high productivity of the tertiary sector, which reaches 188.0 trillion rupiah (Capital Investment Coordinating Board, 2017) ${ }^{2}$. In addition, the economic structure in DKI Jakarta is dominated by tertiary (non-tradable) sector groups. Based on BPS data, until the first semester of 2017, the role of the tertiary sector reached $73.08 \%$, higher than the primary and secondary sectors. On the other hand, in the period 2010-2016, the average worker in West Nusa Tenggara Province was only able to produce an output of 37.56 million rupiah per year. This figure is quite difference with the national average of 65.77 million rupiah per labor per year even though the tourism sector is a priority sector in the economic activities of the province. This is presumably due to the low level of human resources as indicated by the Human Development Index.

1 Pemerintah Provinsi Kalimantan Timur. (2016). Potensi Perkebunan, Pertanian, dan Perternakan. Retrieved July 28, 2018, from http://kaltimprov.go.id/halaman/potensi-perkebunan-pertanian-danperternakan

2 Badan Koordinasi Penanaman Modal. (2017). REALISASI PENANAMAN MODAL PMDN-PMA. Retrieved from https://www2.bkpm.go.id/images/uploads/file_siaran_pers/Paparan_Indonesia_TW_IV__2017_Kepala.pdf 
The NTB province's HDI rates averaged only 63.62, still lower than DI Yogyakarta and Bali as the provinces which also prioritized the tourism sector (both HDI rates were above 70 ).

Figure4 shows a fluctuating pattern of coefficients of variation (CV) in labor productivity per sector. Nationally, it can be seen that only the primary sector labor productivity in Indonesia shows a tendency for convergence, while other sectors do not. It can be seen that there was a decrease in the coefficient of variation in the primary sector in the period 2010-2016. In 2010, the coefficient of variation in the primary sector labor productivity was 0.9674 and continued to decline until 2016 that reached 0.8827 . This indicates a decrease in the dispersion of primary sector labor productivity, or it can be inferred that there are indications of convergence between provinces in Indonesia. Different patterns are shown by a figure of the coefficient of variation in labor productivity in the secondary and tertiary sectors, where both indicate a divergence tendency.

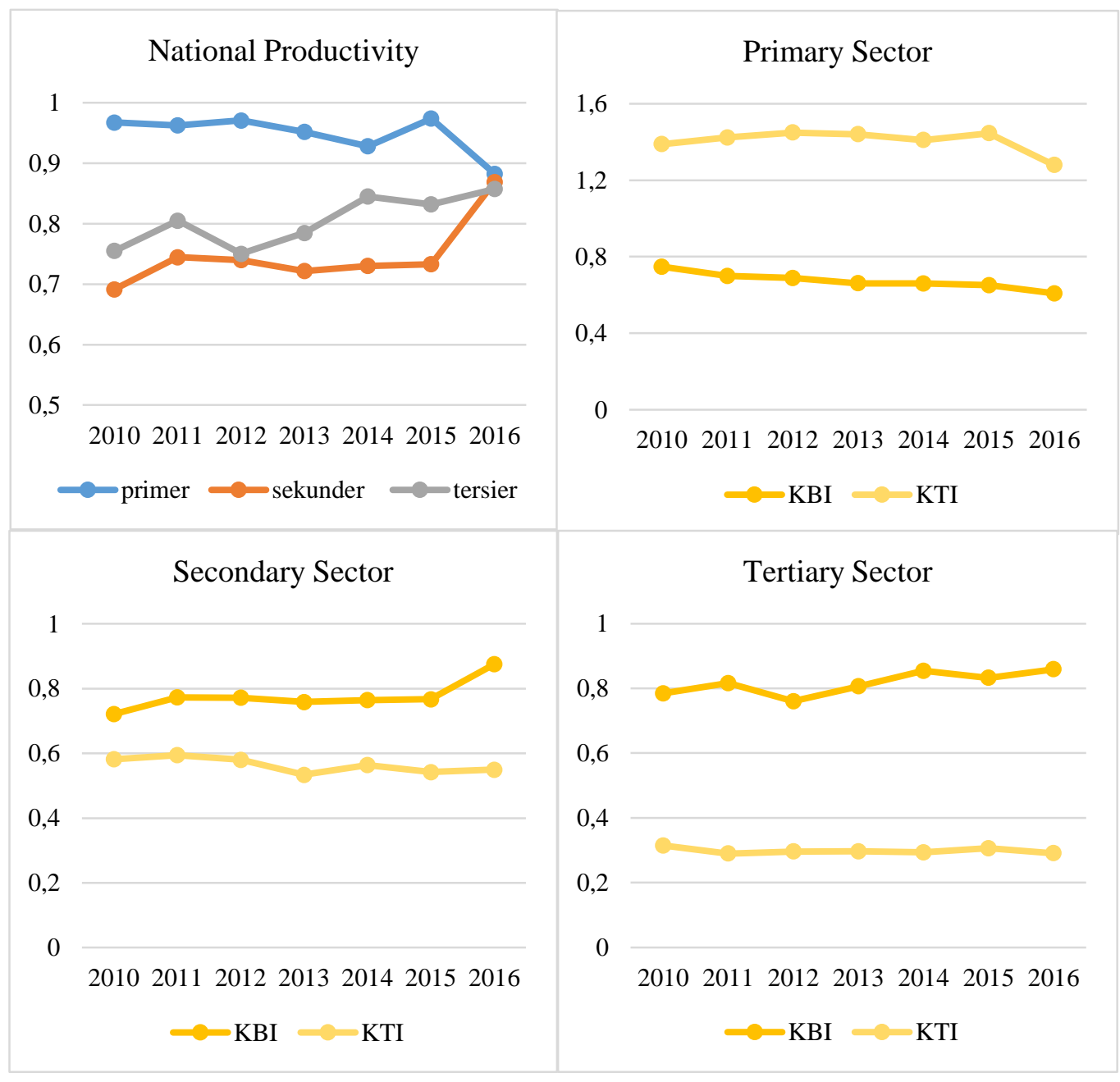

Figure 4. The Coefficient of Variation In Sectoral Labor Productivity In Indonesia In 2010-2016

In terms of the disparity of the Western Indonesia and Eastern Indonesia (next called as KBI and $\mathrm{KTI}$ ), the provinces in Indonesia show a convergence in the primary sector. This indication is shown by the decrease in the dispersion of the coefficient of variation both in KBI and KTI. A decrease in the dispersion of the coefficients of this variation shows a weak convergence. This trend shows that the provinces in Indonesia are moving towards equilibrium and show the decreasing gap in the level of labor productivity of primary sector, both in KBI and KTI. 
The labor productivity in the secondary sector in the provinces of KBI shows a divergence trend during the period 2010-2016. The pattern of divergence is actually caused by the increase in the dispersion of the coefficient of variation in labor productivity secondary sector, which is quite high in 2016, where the value reached 0.8753 . Nonetheless, the convergence pattern is shown by a decrease in the dispersion of coefficient of variation between provinces in Eastern Indonesia (KTI). These results indicate that the labor productivity among provinces in KBI tend to be more easily become unequal or imbalance, while that between provinces in Eastern Indonesia tends to be easy to close the gap.

The tertiary sector also shows a slight pattern of labor productivity divergence in the provinces in KBI. During the 2010-2016 period, the coefficient of variation of the tertiary sector labor productivity in KBI changed from 2010 by 0.7843 to 0.8587 in 2016, while in Eastern Indonesia there was convergence even though it looked very weak and tended to be stagnant. In general, this implies that the development of the tertiary sector between provinces in Indonesia has not changed much.

$$
\begin{gathered}
\ln \left(L P_{l t}\right)_{\text {primary }}=0,9892113 \ln \left(P T K_{i(t-1)}\right)_{\text {primary }} \\
\ln \left(L P_{l t} \widehat{)_{\text {secondary }}}=1,004873 \ln \left(L P_{i(t-1)}\right)_{\text {secondary }}\right. \\
\ln \left(L P_{l t}\right)_{\text {tertlary }}=1,000344 \ln \left(L P_{i(t-1)}\right)_{\text {tertiary }}
\end{gathered}
$$

Based on the estimation results shown in Appendix 1, the results of the $A B$ and Sargan test show that the parameters have been consistent and valid at the $5 \%$ probability of error. The $A B$ m1test rejects the null hypothesis and the results of the $A B \mathrm{~m} 2$ test reject the null hypothesis in each sectoral equation. This gives the conclusion that there is no correlation between errors in both first order and second order. In addition, the Wald test also shows the results of rejecting the null hypothesis which means the lag labor productivity in each sector is significant. Furthermore, the Sargan test shows non-significant results in sectoral equations, but significant in tertiary equations. This indicates that the instrument is invalid when estimations are made. Therefore, Caselli, Esquivel, and Lefort (1996) suggests that it is necessary to add instrument variables by making pair combinations with other independent variables that the researcher has done in the next discussion, namely conditional beta convergence analysis.

The existence of absolute beta convergence of labor productivity can be seen from the regression equation coefficients of the labor productivity in previous year (lag variable). If the coefficient of productivity lag is less than one, it means that there is a convergence condition. The estimation results show that the coefficient of lag of labor productivity is less than one in the primary sector, so there is a convergence. However, in the secondary and tertiary sector equations, the value of the lag coefficient of labor productivity is more than one, which means there is no evidence of convergence.

In general, this conclusion leads to indications that provinces that have lower primary sector labor productivity have an absolute tendency to grow faster than provinces with higher labor productivity, so that inequality between the two regions will decrease. On the other hand, there is no strong evidence that shows the tendency of provinces in Indonesia to close the inequality gaps, especially the secondary and tertiary sectors. This conforms to the results shown by the sigma convergence analysis.

The convergence rate that occurs in absolute beta convergence of primary sector labor productivity and the time needed to achieve half-life convergence conditions can be obtained with the following calculations:

Speed of convergence $(\lambda)=-\ln (0.9892113)=0.01084732$

Half-life convergence $\left(t^{*}\right)=63,9003163$ 
The labor productivity of the primary sector takes a long time, around 63-64 years. This is because the primary sectors such as agriculture and mining exploit a lot of natural resources and tend to be capital intensive even though only a small proportion of provinces in Indonesia that have an abundant natural resource and the potential for superior mining and quarrying and agricultural land. In national aggregate, according to the Mineral in Figures 2011-2016 Director General of Energy and Mineral Resources, during 2013-2016 the average growth of coal production was $1.2684 \%$ which also followed the decline in the production of other minerals such as gold, silver, tin and nickel. In addition, this sector is the biggest employer. Based on the August 2016 Labor Force Report, the total primary sector labor reached 39.24 million or $34.2632 \%$ of the total labor. Therefore, the growth speed towards convergence will be very slow.

The divergence is indicated by the parameter estimation in the secondary and tertiary sector labor productivity equations. It explains that provinces in Indonesia are still having difficulties in achieving labor productivity convergence. Actually, this phenomenon is in line with the descriptive analysis described earlier. This result shows the provincial growth average in secondary sector labor productivity is $0.0936 \%$ per year far below the average growth rate of provinces with high productivity of $4.0656 \%$. While the average growth rate of tertiary sectors in provinces with low productivity of $4.0332 \%$ is empirically unable to catch up with other provinces.

The divergence phenomenon of these two sectors has actually been pointed out from the results obtained in the previous sigma convergence analysis where there was a tendency to increase the dispersion coefficient of variation in labor productivity from both sectors. Firdaus, (2013) explained that the development of the Indonesian economy entered a phase towards the maximum point of the U-Wiliamson curve, so that it was in times of high inequality. In addition, the secondary and tertiary sectors are sensitive to technological development. The development of the processing industry, especially high-tech industries, is only focused on Java, which has caused a wider level of development differences.

In line with the estimation results in absolute beta convergence equations, the primary sector takes the longest time to reach the half convergence condition. With the rate of convergence of 7.59 percent, the time needed by provinces in Indonesia to reach the half convergence condition in primary sector is 9-10 years. It is caused by an average independent variable that is expected to affect the speed of convergence in primary sector labor productivity has the smallest value than other sectors such as the value of GFCF, MYS, and real wages. The results of the calculation of the level of convergence of the secondary sector labor productivity indicate that in the secondary sector, provinces in Indonesia to reach half the convergence of labor productivity is the fastest compared to the primary and tertiary sectors. The time needed to achieve the half-life convergence is 1-2 years. To achieve the half-life convergence condition, the convergence rate is needed at 35.70 percent. Furthermore, from the estimation of the tertiary sector labor productivity equation, the tertiary sector labor productivity between provinces in Indonesia undergoes a convergence process slightly slower than the secondary sector with a convergence rate of 20.12 percent. At such a rate, half the time the convergence process can be achieved within 3-4 years.

The high rate of convergence of labor productivity in the secondary sector compared to other sectors is due to the large contribution of independent variables that accelerate convergence. Based on the estimation results, it can be seen that the coefficients of each of the independent variables in the equation of the secondary sector are the largest among other sectors. The results obtained from the conditional beta convergence rate of labor productivity are in line with Susanti's (2005) study, where the longest convergence rate was the Agriculture Sector and Mining and Excavation Sector, and then followed by tertiary service sectors and secondary sectors such as the Manufacturing and Building Industry. Other studies such as Fitri et al. (2013) also have similar results where labor productivity convergence requires time to half-life convergence around 11 years, then 
the convergence of agricultural sector labor productivity in Indonesia is also slightly slower ( 3 years) compared to the manufacturing sector (2 years).

The positive influence provided by the spatial effect on labor productivity in the primary and secondary sectors and the negative influence in the tertiary sector can be explained in several ways. First, the number of workers in the primary and secondary sectors. Based on the August 2016 Labor Force Report, the total primary sector workforce reached 39.24 million and the secondary sector reached 23.87 million from the total labor. The primary and secondary sector workers tend to have a relatively lower quality of education than the tertiary sector. Tertiary sectors are also sensitive to technological development and require higher quality workers, which can cause very high productivity. So, when migration occurs, the labor productivity of a province will tend to decline, and labor productivity in the surrounding provinces will actually increase due to the transfer of qualified labors. Unlike the case in the primary and secondary sectors, the quality of labors is relatively lower. Labors whose education quality is relatively low will tend to be a burden and reduce productivity, so that when migration occurs it will increase productivity.

In addition, another reason is the possibility of labor shifting when migration occurs (Permata and Prasmuko, 2008). So, when there is a shift in labor, it is also possible to have sectoral shifts of work. Thus, the direction and pattern of the relationship between labor migration and labor productivity is difficult to predict as indicated by the positive direction in the primary and secondary sectors and the negative direction in the tertiary sector.

The primary sector Gross Fixed Capital Formation (GFCF) has a significant positive effect on primary sector labor productivity. The increase in GFCF growth by 1 percent was able to significantly increase the growth of primary sector labor productivity by 0.1072 percent assuming ceteris paribus. GFCF is also a variable that significantly affects labor productivity in the secondary sector. The GFCF coefficient is 0.4642 which means that ceterus paribus, an increase in GFCF growth of 1 percent will increase the growth of secondary sector labor productivity by 0.4642 percent. This figure shows that the secondary sector contributes to a greater labor productivity compared to the primary sector. The tertiary sector labor productivity is also empirically significant influenced by the GFCF tertiary sector. The GFCF coefficient value is 0.1314 . This means that under the ceterus paribus assumption, 1 percent increase in the growth of the tertiary sector GFCF can significantly increase the productivity growth of the tertiary sector by 0.1314 percent. This figure is also slightly larger than the contribution of GFCF to primary sector productivity, but is smaller than the contribution to the productivity of the secondary sector.

Nicolini's (2008) research confirmed that the GFCF has a positive influence on labor productivity. The results of this study are in accordance with the research of Gutierrez (2000) which focuses on the labor productivity of the agricultural sector only. He found strong evidence that where agricultural investment is higher, agricultural labor productivity grows faster. In addition, according to Rahardja and Winkler (2012), the secondary sector tends to require more capital accumulation for its production activities. This increase in GFCF capital accumulation will help increase productivity and help accelerate the convergence process.

The Life Expectancy (LE) is a proxy for labor health. The estimation results show a significant negative effect of LE on labor productivity, where every 1 percent increase in LE will reduce the productivity of the primary sector by 0.4192 percent, the secondary sector by 0.7738 percent, and the tertiary sector by 0.4467 percent. The estimation results of this study are different from initial hypothesis and the previous research (E.Bloom, Canning, and Sevilla, 2004) which say that LE has a positive influence on labor productivity. This phenomenon can be explained where high LE will increase the number of old age population. When the population of old age is high, it will increase the dependency ratio. The higher dependency ratio indicates the higher burden that must be borne by the productive age population. This is reinforced by the data shown in the following figure, where 
from 2010-2016 the number of Indonesia's old age dependency calculated from the percentage of population aged 64 years and over to the total population of productive age (15-64 years).

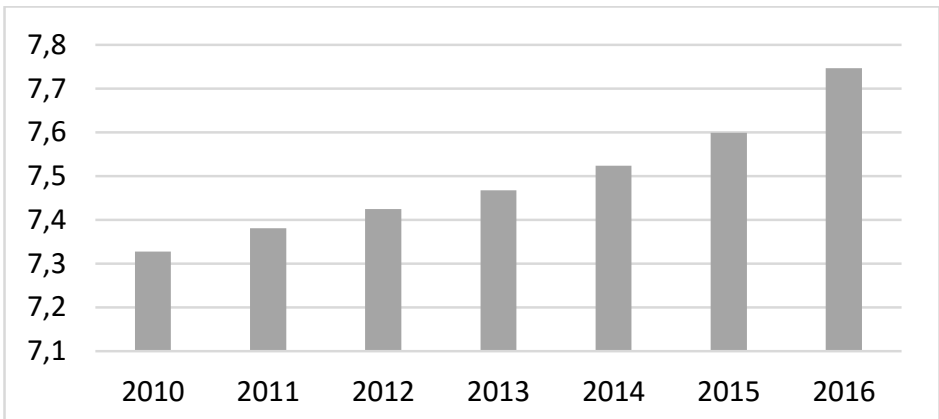

Figure 5. Indonesia Dependency Ratio, Old Age in 2010-2016

Beside that, there are still a large number of elderly labors who are still working, especially in the primary sector. On average, LE in Indonesia is 69 years whereas according to the Indonesian Labor Force Report in August 2016, the number of workers aged 60 years and over in each sector, namely the primary sector reached $6,554,533$ people (16.70 percent), secondary sector $1,146,579$ people (5.49 percent), and tertiary sector $3,096,325$ people (5.60 percent). The elderly population has lower productivity levels than young people, so participation in economic activities is also low. An increase in LE will also increase the population. This is as explained by Maestas, J. Mullen and Powell (2016) where productivity and the proportion of elderly labors have a negative relationship. Other research from Acemoglu and Johnson (2007) also shows that every 1 percent increase in LE will increase 1.35 percent of the population. Along with the increase, of course, it will also increase the number of the workforce. Nevertheless, according to the theory of diminishing product of labor, a continuous increase in the workforce actually decreases average productivity.

Meanwhile, MYS proved to have a significant positive effect on primary sector labor productivity at a 5 percent probability of error. Assuming ceteris paribus, 1 percent increase in MYS growth will be able to increase labor productivity growth in the primary sector by 0.6448 percent. The coefficient of the MYS shows the positive relationship to the secondary sector labor productivity. The coefficient of the MYS in the secondary sector equation also confirms that the contribution of secondary sector education to labor productivity is the largest compared to other sectors. An increase of 1 percent growth in MYS will increase labor productivity in the secondary sector by 1.0164 percent. As for the tertiary sector, 1 percent increase in MYS is only able to increase labor productivity by 0.3409 percent assuming ceteris paribus. The MYS variable turns out to have the largest contribution to the productivity of the secondary sector labor. This is quite in line with Sulistyowati (2010), who argued that the industrial sector (secondary sector) requires a more skilled labor compared to the agricultural sector. The contribution of the MYS to the productivity of the tertiary sector turned out to be empirically the smallest.

Furthermore, the primary sector real wage in the agricultural sector labor productivity equation shows a significant positive relationship. The coefficient of primary sector real wages is 0.0292 . This means that ceteris paribus, each increase in real wages by 1 percent will increase the labor productivity in the primary sector by 0.0292 percent. Meanwhile, the results of this study also show that the secondary sector real wage significantly has a positive influence on labor productivity in secondary sector. The real wage coefficient is 0.0791 . This means that secondary sector labor productivity growth of 0.0791 percent can be obtained by increasing by 1 percent of the secondary sector real wages. The tertiary sector real wage shows a significant positive relationship to the tertiary sector labor productivity with the coefficient value of the tertiary sector real wage0.0498. 
This value contains an interpretation that under ceteris paribus assumption, each increase in real wage by 1 percent will increase the productivity of the tertiary sector by 0.0498 percent.

This result is in accordance with the findings of Sumarlin (2006) that there is evidence of a unidirectional relationship, namely high wages affecting labor productivity in Indonesia. Increasing incentives and wages can significantly increase labor productivity. High wages can provide motivation to the workforce to work harder and achieve higher achievements (Adhadika and Pujiyono, 2014). Thus this result is in accordance with the initial suspicion of research that labor productivity will increase along with the increase in real wages.

\section{CONCLUSION}

Indonesia has problems in labor productivity inequality both in aggregate and sectoral measures. In almost all sectors, East Kalimantan and DKI Jakarta have always been the provinces with the highest levels of labor productivity. In general, regions that still have a low level of sectoral labor productivity are D.I. Yogyakarta, East Nusa Tenggara and West Nusa Tenggara. The analysis of sigma and beta convergence shows a convergence pattern in all three sectors. The result of conditional beta convergence analysis indicates the late convergence rate of the primary sector so that to achieve a half-life convergence condition takes 9-10 years. Meanwhile, the secondary sector needs time to reach half-life convergence conditions about 1-2 years and tertiary sectors about 3-4 years.

The spatial effect significantly affects the growth of labor productivity in all sectors. The estimation of the dynamic spatial model of labor productivity convergence with the Spatially Corrected Blundell-Bond (SCBB) technique shows that variables that significantly influence labor productivity are GFCF, MYS, and real wages, while LE negatively affect productivity labor.

Based on the findings of the study, the researcher recommends to local governments to identify and select low productivity sectors, so that they become a focus for development program. This can be done by establishing competency standards for workers and then relocating the labor to the prioritized sectors. For example, development of the agricultural sector must also be driven by infrastructure development through good investment and industrialization strategies. Thus, not only the primary sector especially agriculture will grow but also other sectors by creating markets for industrial goods and other services.

Further research, can use other spatial weight matrices that can capture the phenomena of spatial linkages and dependencies between provinces in Indonesia. In addition, it is recommended to use alternative specifications of other models such as Spatial Error Model (SEM) to explain spatial linkages.

\section{Limitation of the Research}

This research only focuses on studying the convergence of labor productivity in Indonesia according to three sectors, namely: primary, secondary and tertiary sectors. The scope of this study covers 33 provinces in Indonesia without North Kalimantan because of incomplete data in the study period. The analysis used in this study is spatially dynamic panel data regression analysis focusing on the spatial lag or Spatial Auto Regressive (SAR) model using the Spatially Corrected Blundell-Bond (SCBB) as the estimation technique.

\section{REFERENCES}

Acemoglu, D., \& Johnson, S. (2007). Disease and Development: The Effect of Life Expectancy on Economic Growth. Journal of Political Economy, 115(6), 925-985. https://doi.org/10.1086/529000

Adhadika, T., \&Pujiyono, A. (2014). Analisis Faktor-Faktor Yang Mempengaruhi Di Kota Semarang, $3(1), 1-13$.

Baltagi, B. H. (2005). Econometric Analysis of Panel Data (3rd ed). New York: John Wiley and Sons 
$\begin{array}{llll}\text { Bhinadi, } & \text { A. (1997). Ekonomi } & \text { 39-48. }\end{array}$ https://doi.org/http://dx.doi.org/10.1111/petr.12043

Bouayad-Agha, S., \& Lionel, V. (2010). Estimation strategies for a spatial dynamic panel using gmm. a new approach to the convergence issue of european regions. Spatial Economic Analysis, 5(2), 205-227. https://doi.org/10.1080/17421771003730711

Calvo, Sara and Reinhart, Carmen. (1996). Capital Flows to Latin America: Is There Evidence of Contagion Effects? MPRA Paper No. 7124. Accessed on July 25, 2018, at http://mpra.ub.unimuenchen.de/7124/.

Caselli, F., Esquivel, G., \&Lefort, F. (1996). Reopening the Convergence Debate: A New Look at CrossCountry Growth Empirics. Journal of Economic Growth, 1(3), 363-389. https://doi.org/10.1007/BF00141044

E. Bloom, David \& Canning, David \& Sevilla, Jaypee. (2004). The Effect of Health on Economic Growth. World Development, 32, 1-13. http://dx.doi.org/10.1016/j.worlddev.2003.07.002

Firdaus, M. (2013). Ketimpangan Pembangunan Antar Wilayah di Indonesia: Fakta dan Strategi Inisiatif. Orasi Ilmiah, 54. Accessed on July 24, 2018, from https://www.google.com/url?sa=t\&rct=j\&q=\&esrc=s\&source=web\&cd=2\&cad=rja\&uact $=8 \& v$ ed=2ahUKEwi_uKvPke7cAhUQX30KHTPUA3cQFjABegQICBAC\&url=http\%3A\%2F\%2Fmfirdaus. staff.ipb.ac.id\%2Ffiles\%2F2017\%2F10\%2FORASI_ILMIAH_GURU_BESAR-

72dpi.pdf\&usg=AOvVaw2Q6AqnuXjSu3voOYx7

Fitri, A., Firdaus, M., \& Fahmi, I. (2013). Disparitas, konvergensi, dan determinan produktivitas tenagakerja regional di Indonesia. Jurnal Ekonomi Dan Pembangunan Indonesia, 14(1), 63-81. https://doi.org/10.21002/jepi.v14i1.447

Gutierrez, Luciano. (2002). Why is Agricultural Labour Productivity higher in some countries than others? Agricultural Economics Review, 03(1).

Hasriati, Afni. (2016). Pemodelan Konvergensi Inflasi Antar Wilayah di Indonesia dengan Pendekatan Spasial Dinamis Data Panel AB-GMM dan SYS-GMM. (Master's thesis). Surabaya: Institut Teknologi Sepuluh Nopember. Retrieved June 30, 2018, from http://repository.its.ac.id/41714/1/1314201717-Master-Thesis.pdf

Idris, Aminuddin. (2016). Pengantar Ekonomi Sumber Daya Manusia. Yogyakarta: Deepublish.

Kukenova, Madina dan Monteiro, Jose-Antonio. (2008). Spatial Dynamic Panel Model and System GMM: A Monte Carlo Investigation. MPRA Paper No. 11569. Accessed on June 6, 2018, http://mpra.ub.uni-muenchen.de/11569/

Le Gallo, J., \& Dall'erba, S. (2008). Spatial and sectoral productivity convergence between European regions, 1975-2000. Papers in Regional Science, 87(4), 505-525. https://doi.org/10.1111/j.1435-5957.2007.00159.x

Maestas, Nicole \& Mullen, Kathleen \& Powell, David. (2016). The Effect of Population Aging on Economic Growth. (Working Paper No. 22452). Accessed on August 24, 2019, from National Bureau of Economic Research website: https://www.nber.org/papers/w22452

Millo, G., \& Piras, G. (2012). Journal of Statistical Software splm: Spatial Panel Data Models in R, 47(1). Retrieved from http://www.jstatsoft.org/

Nicolini, Rosella. (2008). Labour productivity in Spain: 1977-2002. Applied Economics, 43(4), 465485. https://doi.org/10.1080/00036840903427216.

Permata, M. I., \&Prasmuko, A. (2010). Fenomena labor shifting dalam pasar tenaga kerja indonesia. Buletin Ekonomi Moneter Dan Perbankan, 12(3), 269-310. https://doi.org/10.21098/bemp.v12i3.243

Rahardja, Sjamsu dan Winkler, Deborah. (2012). Why the Manufacturing Sector Still Matters for Growth and Development in Indonesia. Policy Note 1 the World Bank. Accessed on July 3, 2018, http://siteresources.worldbank.org/EASTASIAPACIFICEXT/Resources/226300-

1349835451376/Full-PN1-Manufacturing.pdf

Sukirno, Sadono. (2012). Mikro Ekonomi. Jakarta: PT. Raja Grafindo Persada. 
Labor Productivity Convergence in .... (Novianto \& Marsisno)

Sumarlin. (2006). Analisis Hubungan Tingkat Upah Tinggi Terhadap Produktivitas di Indonesia, 20062008 (Master's thesis) Retrieved from http://repository.usu.ac.id/bitstream/handle/123456789/4084/06002704.pdf;jsessionid=EF2 32F4EA5C9C683CAEE47E016F73486? sequence $=1$

Susanti, Bety Hayat. (2005). Konvergensi Produktivitas Tenaga Kerja Sektoral Antar Propinsi di Indonesia (1987-2003). (Master's thesis). Depok: Universitas Indonesia. 